\title{
The role of sports marketing in attracting audiences towards less popular sports
}

\author{
Dalia Sedky, Wael Kortam and Ehab AbouAish \\ Business Administration Department, Cairo University, Giza, Egypt
}

Abstract

Purpose - The purpose of this study is to examine how sports marketing can attract audiences towards less popular sports.

Design/methodology/approach - A total of 22 interviews were conducted first to explore the opinions of sports professionals about how audiences can be attracted towards less popular sports. Then 479 responses to an online questionnaire were collected. The online questionnaire includes a pretest-posttest experiment in which each respondent has watched a video. Confirmatory factor analysis, reliability test and hierarchical regression analysis have been performed.

Findings - The elements of sports marketing that can help to attract audiences towards less popular sports are sports media, sports advertising, star athlete and sports sponsorship. The performance of national teams moderates the relationship between sports advertising and attraction towards less popular sports.

Originality/value - To the best of the authors' knowledge, a definition of sustainable sports marketing is introduced for the first time. Sustainable sports marketing can be defined as the continuous implementation of marketing activities in the sports context to ensure the continuous existence of the sports themselves (all types of sports) and the prosperity of future generations. Elements that can attract audiences towards less popular sports have been examined for the first time.

Keywords Sports marketing, Sustainability, Attraction, Less popular sports, Sponsorship, Advertising, Media, Star athlete

Paper type Research paper

\section{Introduction}

In January 2017, the Egyptian national football team played in the Africa Cup of Nations in Gabon. At the same time, the Egyptian national handball team played in the World Men's Handball Championship in France. A total of 100 Egyptians were surveyed by the researchers. They were chosen randomly in a convenient way. Of the respondents, $67 \%$ did not know about the handball championship; however, the majority of the Egyptians followed passionately the national football team. This pushes the researchers to think about the possibility of attracting audiences towards different types of sports other than football. A total of 22 interviews were conducted with sports professionals to explore their opinions about how audiences can be attracted towards less popular sports (discussed later in the methodology section).

(C) Dalia Sedky, Wael Kortam and Ehab AbouAish. Published in Journal of Humanities and Applied Social Sciences. Published by Emerald Publishing Limited. This article is published under the Creative Commons Attribution (CC BY 4.0) licence. Anyone may reproduce, distribute, translate and create derivative works of this article (for both commercial and non-commercial purposes), subject to full attribution to the original publication and authors. The full terms of this licence maybe seen at http://creativecommons.org/licences/by/4.0/legalcode

Role of sports marketing

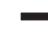

Received 18 April 2020

Revised 1 June 2020

17 July 2020

8 October 2020

Accepted 8 October 2020

(1) 
JHASS
4,2

114

When the taekwondo player Hedaya Malak won a bronze medal in Rio Olympics 2016, media focus was at the peak. Few months later, no one cares. Media focus should be continuous.

As mentioned by the acting executive manager of the Egyptian Taekwondo Federation.

Sports media, sports advertising, star athlete and sports sponsorship are the elements mentioned by the interviewees to attract audiences towards less popular sports. These elements form the integrated sports marketing communication mix. Interviewees have also mentioned that the performance of national teams can attract audiences and media. The stimulus-response theory of learning views any action that is taken by an individual as "a form of learned behavior in response to certain stimuli” (Baker, 1976, p. 69). In this research, sports marketing and its elements (sports media, sports advertising, star athlete and sports sponsorship) are the stimuli. However, attraction towards less popular sports is the response. According to Cialdini et al. (1976) and Kwak et al. (2015), performance of national teams has been used as a moderator (as discussed later).

The purpose of this research is to examine how sports marketing can attract audiences towards less popular sports. Arora and Hartley $(2017$, p. 6) have asked a question: "How can a positive sustainable world be initiated?" Trying to find an answer to their question, this research aims to introduce the concept of sustainability to sports marketing. A definition of sustainable sports marketing is introduced for the first time. This research aims not only to provide insights to academic researchers and sports practitioners, but also to protect future generations from the dangers of drugs and terrorism by attracting them to different types of sports. The following paragraphs cover the literature review and hypotheses, research methodology, data analysis and findings, discussion, implications, limitations and future research.

\section{Literature review and hypotheses}

\subsection{Less popular sports}

Oxford Dictionary (2018a) defines the word "popularity" as the state of being liked by many people. Accordingly, "less popular" means liked, but not by many people. In the current research, less popular sports refer to sports with a small base of audiences. Football is the most popular sport in Egypt (Ebrahim et al., 2018). Football in Australia is called soccer; however, it "struggles" to attract media coverage (Vann et al., 2015, p. 108). This indicates that the popularity of a certain sport differs from one country to another depending on the size of its audiences.

The word "niche" is not used in the current research because a market niche refers to "a very homogenous group of consumers" (Shank and Lyberger, 2015, p. 242). The audiences of niche sports are more homogenous than those of popular sports (Greenhalgh and Greenwell, 2013). However, the purpose of the current research is to widen the base of audiences of less popular sports and attract individuals from different segments. Similarly, the word "grassroots" is not used because it refers to amateur or non-professional games that anyone can play as a leisure activity (European Commission Report, 2016).

Miloch and Lambrecht (2006) have considered sports such as archery, cycling and bowling as less popular sports because they are not mainstream and do not have a wide base of audiences. Girginov and Hills (2008) have chosen to study volleyball in the UK because it does not have publicity and funding as other sports. Schwarzenberger and Hyde (2013) have described trail running in New Zealand as a less popular sport because of its small base of audiences and limited media coverage. Vann et al. (2015) have described netball in Australia as a less popular sport because of the limited media coverage. 
Sparks and Westgate (2002) have described Canadian women's ice hockey as a less popular sport, when compared with men's hockey games which have a wide base of audiences and broad media coverage. Trail and Kim (2011) have chosen to study women's basketball games because they are less popular than football and men's basketball in the USA. Although tennis has witnessed a huge increase in its base of audiences in China, the sport still faces many challenges (Xu et al., 2017). Mackintosh et al. (2014) have recommended thinking out of the box to increase the popularity of sports. They have examined the program, created by the English Table Tennis Association, which provides flexible outdoor table tennis facilities to assure the sustainability of the sport itself.

\subsection{Attraction}

Funk and James (2001) have developed the psychological continuum model, which is composed of four stages - awareness, attraction, attachment and allegiance - to examine how people are psychologically connected with sports. Attraction, in social psychology literature, has been examined between individuals and is referred to as interpersonal attraction (Singh and Simons, 2010). In the sports context, Bee and Havitz (2010, p. 40) have referred to attraction as the "interest" of a person in a certain sport. Attraction to a sport is formed because of several factors such as personal, psychological and environmental factors which react together producing "interest and liking for" a certain sport (Funk, 2008, p. 110). The next paragraphs discuss these two terms "interest" and "liking".

If one is interested in something, it means that one cares about it (Harackiewicz and Hulleman, 2010). Hidi and Renninger (2006) have defined interest as the tendency to become involved in certain matters or activities. Interest can be classified into two types: individual (personal) interest and situational interest (Silvia, 2006). Individual interest refers to the interest that is formed because of the accumulated knowledge and values of a person and is shaped by his/her personality and traits, whereas situational interest refers to the instant affection that arises because of external factors and may last for a short time (Harackiewicz and Hulleman, 2010).

Situational interest can be maintained to last for a long time through continuous exposure to the external factors, which gives individual interest a chance to be developed (Silvia, 2006). Individual interest is difficult to be managed because it is related to a person's background; however, situational interest can be fostered by inducing certain catalysts that motivate people to be interested in a certain object (Hidi and Renninger, 2006). The current research handles only situational interest by studying how sports marketing activities can induce people to be interested in less popular sports.

Schraw and Lehman (2001, p. 23) have defined interest as "liking and willful engagement in a cognitive activity". Interest and liking have been used interchangeably by these two authors. In the current research, both terms are used interchangeably because studying consumers' interest in or liking for less popular sports will give the same meaning. Based on what has been previously mentioned, the definition of attraction that has been adopted by this research is "the interest in and liking for a certain sport". In the pretest-posttest experiment which has been conducted, attraction is measured using this definition (discussed later in the methodology section).

Attraction has been examined in a few sports context research studies (Filo et al., 2008; Bee and Havitz, 2010; Hoegele et al., 2014b). Filo et al. (2008) have examined the motives that can attract individuals to charity sports events. Hoegele et al. (2014b) have examined individuals' attraction to German football stars, who play for competing teams. They have measured attraction to competition by asking whether an individual's preferred star plays for his/her preferred team or for a competing team. 
JHASS

4,2

116

Bee and Havitz (2010) have examined individuals' attraction to women's professional tennis using Madrigal's (2006) scale. According to Madrigal (2006), the factors for which individuals experience sports events are fantasy, flow, evaluation, personalities, physical attractiveness and aesthetics. Madrigal's (2006) scale is different from Wann's (1995) scale. Wann's (1995) scale includes eustress, self-esteem, escape, entertainment, economic, aesthetic, group affiliation and family dimensions. Funk (2008, p.117) has referred to the dimensions of both scales as the "benefits" that individuals can get from sports. Madrigal's (2006) scale focuses on sports events consumption; however, Wann's (1995) scale focuses on individuals' interest in sports (Madrigal, 2006). In the five-point Likert-type scale question of the questionnaire, attraction is measured using items adapted from Wann's (1995) scale (discussed later in the methodology section).

\subsection{Sports marketing}

Sports marketing can be used to increase fan's interest, sports participation and the consumption of sports-related products (Ratten, 2016). The elements of the sports promotion mix include advertising, sponsorship, public relations, personal selling and sales promotion (Shank and Lyberger, 2015). Hopwood (2007, p. 213) has used the term "sports integrated marketing communications mix" to describe the traditional promotion mix. She has proposed that this mix is broad enough to include elements other than the traditionally known ones to cope with the features of the sports products.

Turner (2017) has examined the integrated marketing communication activities that were used during the Asian Cup 2015. He has found that advertising, publicity, public relations, sales promotions and digital communications were executed by the event organizers. Ramachandran (2008) has suggested that sports marketing can help to increase the popularity of sports other than cricket in India. Sports marketers have to recognize what can attract audiences (Ratten, 2016). Based on this argument, the following hypothesis can be formulated:

H1. Sports marketing attracts audiences towards less popular sports in a significant positive way.

2.3.1 Sports media. Television (TV), radio, the internet and newspapers are considered as the most important outlets of mass media because they are accessed by a large number of people all over the world (Funk, 2008). Media coverage means the amount of attention given by media to shed light on a certain issue (Shank and Lyberger, 2015). The newspapers coverage of the American and Canadian men's ice hockey teams, competing in the 2010 Winter Olympic Games, are more than that of the women's teams (Vincent and Crossman, 2012). When TV media coverage is little or absent, social media can be used to promote sports where fans can control the content (Vann et al, 2015).

Ritchie et al. (2010) have noted the importance of media coverage in influencing individuals' support for mega sports events such as the Olympic Games. The theory of agenda-setting assumes that mass media is able to shape individuals' way of thinking (Kim et al., 2015). Brown and Bryant (2006) have noted the importance of sports programs in influencing how audiences view the games. Zeng et al. (2011) have emphasized the importance of TV media coverage in enhancing audiences' opinions. If a certain issue is covered by media continuously, individuals will pay it more attention (Kim et al., 2015). Accordingly, $H 1$ can be divided into the following sub-hypothesis:

H1a. Sports media attracts audiences towards less popular sports in a significant positive way. 
2.3.2 Sports advertising. Advertising can help to develop the attraction of audiences towards sports (Funk, 2008). Advertising is used to tell, convince and remind consumers about certain products (Kotler and Armstrong, 2016). One of the issues that has been observed from RIO Olympics 2016 is that companies prefer sport as a channel for advertising because audiences follow the games live and there is a little chance to miss the advertisements (Plutsky, 2016). Using sports as channels to advertise can help to create good responses towards advertisements because of the glamor of the games (Pyun and James, 2011). Kim(Yongjae) et al. (2013) have recommended marketers to make marketing advertisements that emphasize patriotic values during sports events such as the Olympic Games because patriotic advertisements result in creating good reactions towards the advertised brand.

Virtual advertising is a non-conventional form of advertising used by companies, which refers to digital advertising that shows the brands and logos of advertisers during a televised sports event in any free space on the screen (Sander and Altobelli, 2011). However, according to the same authors, virtual advertising is not an appropriate tool for launching new brands. Advertising can be product-focused or company-focused (Söderman and Dolles, 2015). Product-focused advertising tries to convince people to buy a certain product (Pyun and James, 2011). However, the goal of company-focused advertising is to make good impressions of the company by highlighting its corporate social responsibility efforts (Söderman and Dolles, 2015). In this research, less popular sports are the products. The aim of advertising here is to promote less popular sports. Accordingly, $H 1$ can be divided into the following sub-hypothesis:

$H 1 b$. Sports advertising attracts audiences towards less popular sports in a significant positive way.

2.3.3 Star athlete. Hyman and Sierra (2010) have used the word "celebrities". Hoegele et al. (2014a, 2014b) have used the word "superstars". Liu and Brock (2011) have used several words in the same paper such as popular athletes and sports stars. In this research, the researchers have chosen to use the words "star athlete" for the purposes of differentiation and specification.

Hoegele et al. (2014a) have defined a star athlete as a player who excels in his/her performance and has an outstanding popularity. The researchers want to add the code of ethics to this definition. It is important that a star athlete has good manners and keeps the code of ethics of sports. The respondents of the questionnaire (as mentioned later in the discussion part) have emphasized this point of view.

According to the theory of meaning transfer (McCracken, 1989), the image of the star is transferred to the product and from the product to the consumer. Star athletes can influence the decisions of young people in Australia to change brands (Dix et al., 2010). The attractiveness of the star is the most important characteristic that can affect young Egyptians' intentions to buy, especially the females (AbouAish, 2011).

Star athletes are able to attract new fans towards their teams and protect existing fans from being lost to other competing teams (Hoegele et al., 2014b). Star athletes can be used as endorsers to promote the products of sponsors and attract consumers (Liu and Brock, 2011). In a similar way, star athletes can be used as endorsers of the sports themselves, especially less popular sports, to attract audiences. Accordingly, $H 1$ can be divided into the following sub-hypothesis:

H1c. Star athlete attracts audiences towards less popular sports in a significant positive way. 
JHASS

4,2

\section{8}

2.3.4 Sports sponsorship. Sports sponsorship is an element of the promotion mix where an exchange exists between a sponsor and a sports entity (athlete, league, team or event) for the benefit of both sides (Shank and Lyberger, 2015). This goes in accordance with the theory of social exchange which states that individuals are inclined to build relationships where benefits are exchanged (Inoue et al., 2016). Sports catch greatly the attention of sponsors because they can reach audiences all over the world and affect their attitudes (Plewa and Quester, 2011).

Linking corporate social responsibility programs with sports sponsorship has a positive impact on company's reputation, word of mouth and consumption behaviors (Walker and Kent, 2009). Corporate social responsibility in sports can be in the form of actions that support the environment, cultural diversity, disability, etc. (Djaballah et al., 2017). From the researchers' point of view, supporting less popular sports can be one of the forms that links corporate social responsibility with sports sponsorship. Companies are trying to discover new sponsorship opportunities to avoid the crowd of sponsoring popular sports (Shank and Lyberger, 2015). Therefore, sponsoring less popular sports can be a new opportunity for them to exploit.

Sponsoring less popular sports can offer sponsors advantages such as avoiding the crowd of sponsorship, cost savings and the flexibility of the sports entity (Greenhalgh and Greenwell, 2013). Red Bull has sponsored action sports to be known among audiences (Kunz et al., 2016). Marketers can offer attractive sponsorship proposals that motivate companies to sponsor less popular sports (Miloch and Lambrecht, 2006). Thus, $H 1$ can be divided into the following sub-hypothesis:

H1d. Sports sponsorship attracts audiences towards less popular sports in a significant positive way.

\subsection{Sustainability, sustainable marketing and sustainable sports marketing}

Sustainability is the ability to keep something in existence continuously (Balbinot and Borim-De-Souza, 2012). Sustainability is a concept, that is globally adopted, which aims to enhance the well-being of humankind (Nkamnebe, 2011). Kotler and Armstrong (2016, p. 627) have defined sustainable marketing as "socially and environmentally responsible marketing" that satisfies the needs of customers and companies and at the same time meets the needs of future generations.

Oxford Dictionary defines sustainability as the ability to be maintained at a certain rate or level (Oxford Dictionary, 2018b). In September 2015, more than 150 world leaders attended the United Nations Sustainable Development Summit in New York where they have committed to adopt the 2030 Agenda for sustainable development (United Nations, 2015). The International Olympic Committee has started to adopt the concept of "sustainable sports development" since 2002 (Girginov and Hills, 2008, p. 2092). This means that marketing activities, to promote sports, are needed to be done continuously.

This research aims to introduce the concept of sustainability to sports marketing. Sustainable sports marketing can be defined as the continuous implementation of marketing techniques in the sports context to ensure the continuous existence of the sports themselves (all types of sports) and the prosperity of future generations. Attracting people to different types of sports may protect future generations from the dangers of drugs and terrorism. This goes in accordance with the theory of utilitarianism which states that the principal goal of one's action is attaining the welfare of humankind (Nakano-Okuno, 2011). 


\subsection{Performance of national teams}

For the purpose of easy writing, "national performance" has been used in this research to refer to the "performance of national teams" variable. Both names have been used interchangeably. Jang et al. (2015) have found that team performance is an important element which participates in building the reputation of the team. They have defined team performance as the performance that audiences perceive which results in winning. Team performance influences consumers' intentions to buy the products of sponsors (Ngan et al., 2011). Kwak et al. (2015) have examined the moderating role of team performance on marketing consumers' intentions to buy products that carry the logo or name of the team. They have found that when a team performs well, this increases the possibility of buying team-related products.

"Basking in reflected glory" concept was developed by Cialdini et al. (1976) to reflect the inclination of people to relate themselves to the success of others although they have not participated in the process of this success. This explains why fans consider the achievements of their teams as their own (Dalakas et al., 2004). The French Handball Federation is trying to attract audiences by highlighting the achievements of the national team (Hautbois and Bouchet, 2015). Companies can invest in the achievements of teams by organizing marketing campaigns that relate themselves to these achievements (Dalakas et al., 2004). In a similar way, triumphs of national teams can be highlighted to attract audiences towards less popular sports. According to Cialdini et al. (1976) and Kwak et al. (2015), the researchers have incorporated the performance of national teams as a moderator to study its effect on the relationship between sports marketing and attraction towards less popular sports. Thus, the following hypothesis can be developed:

H2. The performance of national teams moderates the relationship between sports marketing and attraction towards less popular sports.

As previously mentioned, the elements of sports marketing are sports media, sports advertising, star athlete and sports sponsorship. Therefore, $\mathrm{H} 2$ can be divided into the following sub-hypotheses:

H2a. The performance of national teams moderates the relationship between sports media and attraction towards less popular sports.

$H 2 b$. The performance of national teams moderates the relationship between sports advertising and attraction towards less popular sports.

$H 2 c$. The performance of national teams moderates the relationship between star athlete and attraction towards less popular sports.

H2d. The performance of national teams moderates the relationship between sports sponsorship and attraction towards less popular sports.

\section{Research methodology}

This research is a cross-sectional one where data have been collected at one period of time (Sekaran, 2003). The research design used is a mixed-methods design known as exploratory sequential design where qualitative data have been first collected to explore a certain phenomenon, and then quantitative data have been collected to examine relationships found in the qualitative data (Creswell, 2012). Regarding the qualitative part of the research, a judgment sample was used because the interviewees were chosen based on the judgment of the researchers. A total of 22 unstructured, open-ended, face-to-face interviews were 
JHASS

4,2

conducted with sports professionals (coaches and managers of clubs, federations and Ministry of Youth and Sports). Each interview was around 40 minutes long, where notes were taken. Interviews were conducted till theoretical saturation was reached (Bryant, 2017). These interviews have provided insights that have helped to choose the research variables, develop the research model and formulate the research hypotheses.

Regarding the quantitative part of the research, a quota sample has been used where gender has been taken into consideration. An online questionnaire has been used because it has included a video that needs to be watched by each respondent. The population elements are all Egyptians whose ages start from 18 years old. The sample subjects are the Egyptians that surf the internet, especially facebook. Sekaran (2003) has provided a table that shows a generalized scientific guideline for sample size decisions. According to that table, the sample size is 384 .

Because the response rate to an online questionnaire is low (Malhotra, 2015), 1520 facebook messages have been sent randomly to individuals that are not known to the researchers after checking their facebook accounts to make sure that they are Egyptians. A total of 479 responses to the questionnaire have been received in 53 days. This is more than the decided sample size (384).

The questionnaire (designed using Google Forms) includes 27 statements to measure the independent, the moderator and the dependent variables. The scales items used to measure sports media, sports advertising, star athlete, sports sponsorship and national performance are adapted from Schlinger (1979), Arai et al. (2013) and Speed and Thompson (2000) and are also developed based on insights from the qualitative interviews and literature review (Cialdini et al., 1976; Dalakas et al., 2004; Vincent and Crossman, 2012). The measurement scale used is a five-point Likert-type scale. The scale items used to measure each variable are given codes.

Attraction is measured using items adapted from Wann's (1995) scale. Wann's (1995) scale includes 8 dimensions represented by 23 items. Some dimensions and items are excluded or grouped together. For example, economic dimension is entirely removed because it refers to gambling, which is unaccepted in the Egyptian society. Self-esteem dimension refers to the glory that individuals feel because of the victory of their preferred teams (Wann, 1995). Self-esteem dimension is excluded to prevent any kind of multicollinearity between such a dimension and the moderator of the research (performance of national teams).

Eustress dimension refers to the positive stress that arises from the unpredictable results of the game (Wann, 1995). Escape dimension refers to individuals' needs to separate themselves from routine activities (Wann, 1995). On the other hand, entertainment dimension refers to individuals' desires to enjoy life (Wann, 1995). Escape and entertainment dimensions can be merged together into one dimension "escaptertainment", which means that one escapes from daily routine pressure to enjoy life.

Similarly, group affiliation dimension and family dimension can be grouped together in one dimension "social interaction" as named by $\operatorname{Kim}(\mathrm{Yu})$ et al. (2013, p. 40) because they refer to individuals' desires to avoid being alone. The final dimension is aesthetics which refers to the artistic feature of sports (Wann, 1995). This dimension is excluded to prevent any kind of multicollinearity between such a dimension and the independent variable (star athlete) because both are related to the performance of athletes.

Attraction is measured using three dimensions which are escaptertainment, social interaction and eustress. Escaptertainment is represented by two statements in the questionnaire, social interaction is represented by one statement and eustress is represented 
by one statement. Attraction scale consists of four statements. Therefore, it is decided to treat attraction as a first-order construct.

The questionnaire includes a pretest-posttest experiment. One-group pretest-posttest design is a type of pre-experimental designs "in which a group of test units is measured twice, before and after exposure to the treatment" (Malhotra, 2015, p. 165). The respondents of the questionnaire have been asked first about whether they will follow a sport event, which will be held in Egypt in 2021, relating to a sport other than football. Then they have watched a video, after which they have been asked again whether they are "interested in and like to" (i.e. attracted to) follow the same sport event.

The video is an advertisement about the World Men's Handball Championship which will be held in Egypt in 2021. It includes the appearance of a star athlete, the names of sponsors of an old sport event and the name of a TV channel. It shows the performance of the Egyptian national handball team in an old sport event. The video's duration is about 21 seconds. It includes a song that is played from its beginning and scenes of audiences' cheers. This video is created by the researchers.

The questionnaire also includes a question that asks about the demographic characteristics of the respondents. The questionnaire was translated into Arabic. Backward translation was done. A pilot test of 20 sample units was conducted to check the difficulties perceived by the respondents. The collected data were revised and tabulated using SPSS. A confirmatory factor analysis (using AMOS) was done to assess the convergent and discriminant validity of the constructs.

Convergent validity can be assessed using factor loadings and average variance extracted whose values should be 0.5 or higher as an indication of adequate convergence (Hair et al., 2014). Table 1 shows that the factor loadings of all scales items are above 0.5, indicating adequate convergent validity except the third item of star athlete variable (star athlete 3) which has a factor loading of 0.350 . Therefore, it has been removed. Although (media 3 ) item has a factor loading of 0.764 , it has been decided to remove it because its removal will enhance the final regression estimates. The following statistical analysis excludes these two items (star athlete 3 ) and (media 3). The values of the average variance extracted of sports media, sports advertising, star athlete, sports sponsorship, national performance and attraction variables are $0.5,0.592,0.504,0.673,0.5$ and 0.57 , respectively, indicating adequate convergent validity.

Discriminant validity is assessed by "comparing the average variance extracted values for any two constructs with the square of the correlation estimate between these two constructs" (Hair et al., 2014, p. 620). Table 2 shows that the average variance extracted values (written in italic) are greater than the squared correlation values, indicating adequate discriminant validity. A reliability test was performed to indicate the internal consistency of the items of each scale using SPSS. The recommended level of Cronbach's alpha is 0.70 or higher (Hair et al., 2014). Sports media, sports advertising, star athlete, sports sponsorship, national performance and attraction have Cronbach's alpha values of 0.715, 0.894, 0.803, $0.889,0.784$ and 0.836 , respectively, indicating a satisfactory level of internal consistency.

\section{Data analysis and findings}

A total of 479 valid responses to the online questionnaire were received. The demographic characteristics of the sample are shown in Table 3. The overall mean of sports media, sports advertising, star athlete, sports sponsorship, national performance and attraction variables are 4.30, 4.07, 4.53, 3.99, 4.13 and 3.75, respectively. A hierarchical regression analysis has been conducted using SPSS to measure the impact of the moderator variable on the relationship between the independent variables and the dependent one (Berkman and Reise, 2012). A 
JHASS

122

Sports advertising

Star athlete

Scales items codes

Factor loadings

Sports media

Media 1

0.680

Media 2

0.709

Media 3

0.764

Media 4

0.641

Advertising 1

0.775

Advertising 2

0.740

Advertising 3

0.833

Advertising $4 \quad 0.805$

Advertising $5 \quad 0.788$

Advertising $6 \quad 0.665$

Star athlete $1 \quad 0.643$

Star athlete $2 \quad 0.658$

Star athlete $3 \quad 0.350$

Star athlete $4 \quad 0.750$

Star athlete $5 \quad 0.779$

Sports sponsorship

Sponsorship 1

0.728

Sponsorship $2 \quad 0.856$

Sponsorship $3 \quad 0.856$

Sponsorship $4 \quad 0.833$

National performance

National performance $1 \quad 0.684$

National performance $2 \quad 0.693$

National performance $3 \quad 0.644$

National performance $4 \quad 0.797$

Attraction 1

Attraction 2

Table 1.

Attraction

Attraction 3

0.805

Scales items' factor loadings

Attraction 4

0.697

\begin{tabular}{lcccccc}
\hline Variables & $\begin{array}{c}\text { Sports } \\
\text { media }\end{array}$ & $\begin{array}{c}\text { Sports } \\
\text { advertising }\end{array}$ & $\begin{array}{c}\text { Star } \\
\text { athlete }\end{array}$ & $\begin{array}{c}\text { Sports } \\
\text { sponsorship }\end{array}$ & $\begin{array}{c}\text { National } \\
\text { performance }\end{array}$ & Attraction \\
\hline $\begin{array}{l}\text { Sports media } \\
\text { Sports advertising }\end{array}$ & 0.500 & & & & & \\
Star athlete & 0.108 & 0.592 & & & & \\
$\begin{array}{l}\text { Sports sponsorship } \\
\text { National }\end{array}$ & 0.284 & 0.199 & 0.504 & & & \\
performance & 0.159 & 0.217 & 0.221 & 0.673 & & \\
Attraction & 0.156 & 0.199 & 0.179 & 0.184 & 0.500 & \\
\hline
\end{tabular}

hierarchical regression analysis also measures the impact of the independent variables on the dependent variable before using the moderator variable.

Variables named "interaction (1), (2), (3), and (4)" are formed by multiplying each independent variable by the moderator after centering (subtracting the mean from each observation value) the independent variables and the moderator variable to avoid multicollinearity (Field, 2013). These variables are formed to examine the interaction effect of the moderator variable on the relationship between the independent variables and the dependent one (Field, 2013). A hierarchical regression analysis enters all variables at one time in three blocks. The first block includes the independent variables, the second block 
Demographic characteristics

Gender

Male

Female

Age

$18-29$

$30-39$

40-49

50 years and more

$\mathrm{Job}$

Housewife

Employee (public or private sector)

Private business owner

University student

On pension

Unemployed

Education

Post-graduate degree

University degree or equivalent

High school or equivalent

Role of sports marketing

Table 3.

Sample's demographic characteristics

includes the moderator and the third block includes the interaction variables to measure the change in $R^{2}$.

Table 4 shows that the assumption of no multicollinearity is supported because the values of the tolerance are greater than 0.10 and the values of the variable inflation factor (VIF) are less than 10 (Hair et al., 2014). Table 4 shows that F-test is significant $(\phi=0.000)$. Table 4 also shows that the independent variables (sports media, sports advertising, star athlete and sports sponsorship) explain $27.7 \%$ of the variance of the dependent variable (attraction towards less popular sports).

The coefficient $(B)$ of sports media variable is $0.144(\phi=0.039)$, which means that as sports media increases by one unit, attraction will increase by 0.144 unit. Therefore, sports media attracts audiences towards less popular sports in a significant positive way. Thus, $H 1 a$ is supported at $95 \%$ confidence level. The coefficient $(B)$ of sports advertising variable is $0.210(p=0.002)$, which means that as sports advertising increases by one unit, attraction will increase by 0.210 unit. Therefore, sports advertising attracts audiences towards less popular sports in a significant positive way. Thus, $H 1 b$ is supported at $95 \%$ confidence level.

The coefficient $(B)$ of star athlete variable is $0.340(p=0.000)$, which means that as star athlete increases by one unit, attraction will increase by 0.340 unit. Therefore, star athlete attracts audiences towards less popular sports in a significant positive way. Thus, $H 1 \mathrm{c}$ is supported at $95 \%$ confidence level. The coefficient $(B)$ of sports sponsorship variable is 0.155 ( $~(x=0.006)$, which means that as sports sponsorship increases by one unit, attraction will increase by 0.155 unit. Therefore, sports sponsorship attracts audiences towards less popular sports in a significant positive way. Thus, H1d is supported at 95\% confidence level.

When the national performance variable (moderator) is entered, $R^{2}$ is increased from $27.7 \%$ to $40.5 \%$. There is a significant positive relationship between the national performance variable (moderator) and attraction towards less popular sports $(\phi=0.000)$. 
JHASS

4,2

124

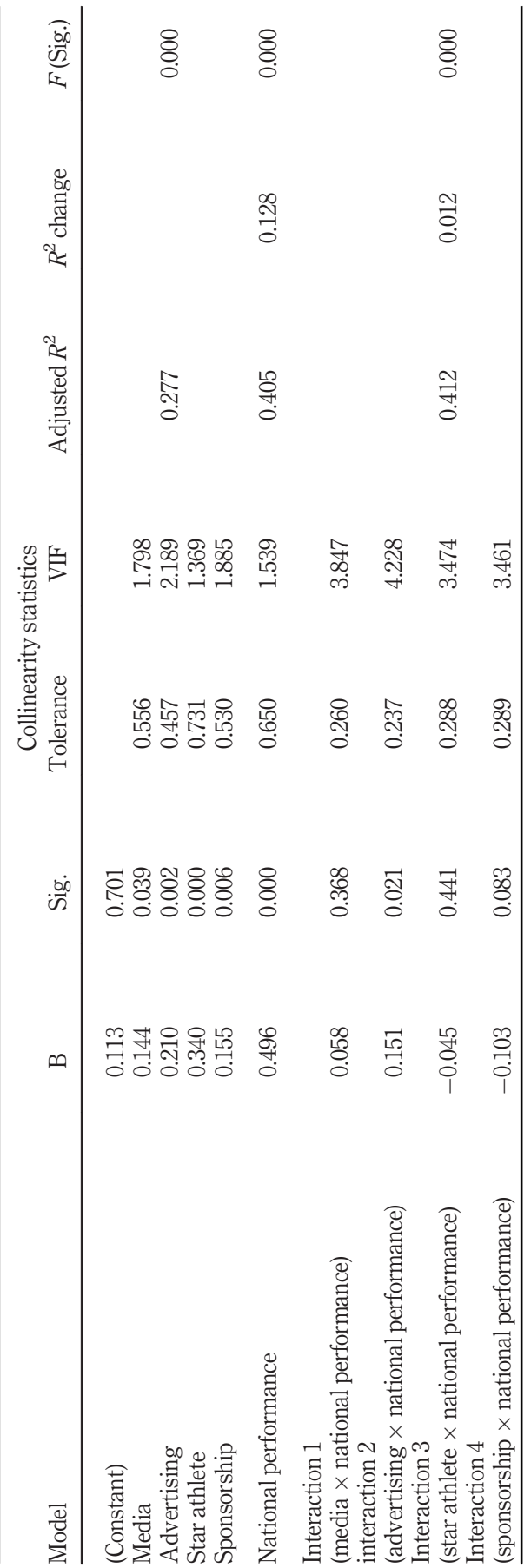

Table 4.

Hierarchical regression analysis results 
When the interaction variables are entered, $R^{2}$ is increased from $40.5 \%$ to $41.2 \%$. Table 4 shows that the relationship between interaction 1 variable (product of multiplication of media and national performance variables after centering them) and attraction is not significant $(p=0.368)$. Therefore, national performance variable does not moderate the relationship between sports media and attraction. Thus, $H 2 a$ is not supported.

Table 4 shows that the relationship between interaction 2 variable (product of multiplication of advertising and national performance variables after centering them) and attraction is significant $(\phi=0.021)$. As national performance increases by one unit, the influence of sports advertising on attraction towards less popular sports will increase by 0.151 unit. Therefore, national performance variable moderates the relationship between sports advertising and attraction. Thus, $H 2 b$ is supported at $95 \%$ confidence level. The influence of sports advertising on attracting audiences towards less popular sports increases when the themes of advertisements focus on the achievements of national teams.

Table 4 shows that the relationship between interaction 3 variable (product of multiplication of star athlete and national performance variables after centering them) and attraction is not significant $(\phi=0.441)$. Therefore, national performance variable does not moderate the relationship between star athlete and attraction. Thus, $H 2 c$ is not supported. Table 4 also shows that the relationship between interaction 4 variable (product of multiplication of sponsorship and national performance variables after centering them) and attraction is not significant $(\phi=0.083)$. Therefore, national performance variable does not moderate the relationship between sports sponsorship and attraction. Thus, $H 2 d$ is not supported.

To sum up, it can be concluded that $H 1 a-H 1 d$ hypotheses are supported. Thus, $H 1$ is supported at $95 \%$ confidence level. This means that sports marketing attracts audiences towards less popular sports in a significant positive way. It can also be concluded that $H 2 a$, $H 2 c$ and $H 2 d$ are not supported; however, $H 2 b$ is supported. Thus, $H 2$ hypothesis is not supported except for sports advertising element. This means that the performance of national teams does not moderate the relationship between sports marketing and attraction towards less popular sports except for sports advertising element.

\section{Discussion}

Although the hypotheses of this research have been tested using scales items as previously mentioned, the researchers have decided to expose the respondents of the questionnaire to a pretest-posttest experiment in which each respondent has watched a video (as discussed in the methodology section). Before watching the video, the answers of the respondents show that $66 \%$ of them will follow the news of an international sport event which will be held in Egypt in 2021, whereas 34\% of them have mentioned that they will not follow. After watching the video, $17.3 \%$ of the respondents have mentioned that they are not interested in or like to follow the news of this championship. It can be noticed that the percentage of the respondents who are not "interested in or like to" (i.e. attracted to) follow the news of this championship have decreased from $34 \%$ to $17.3 \%$ after watching the video. It can be concluded that designing attractive marketing campaigns can attract audiences towards less popular sports and change their way of thinking.

Egyptians are eager to sports other than football. They want media to shed more light on less popular sports. Of the respondents, $78.5 \%$ encourage increasing the amount of coverage allocated to less popular sports in the news. A total of $87.1 \%$ of them encourage making programs about less popular sports local competitions. This is because most of the news and programs are about football. Of the respondents, $89.8 \%$ assure that light should be shed on 
JHASS

4,2

children and young people who are participating in less popular sports local competitions. Young people may change future generations' behaviors regarding these sports.

Egyptians support the idea of making less popular sports advertisements. Of the respondents, $81.2 \%$ encourage making advertisements that induce people to follow less popular sports. A total of $84.9 \%$ of them agree that advertisements (if existed) will increase their knowledge about less popular sports. Egyptians give great consideration to the manners of athletes. Watching fights between football players drives them to search for good examples in less popular sports. Of the respondents, $92.7 \%$ prefer less popular sports athletes who respect their competitors. A total of $85 \%$ of them prefer less popular sports athletes who are socially responsible towards their society.

Egyptians appreciate companies which support less popular sports because these companies serve their society. Of the respondents, $75.2 \%$ encourage companies to sponsor less popular sports. A total of $78.3 \%$ of them agree that sponsoring less popular sports is a corporate social responsibility towards the society. Egyptians are affected by less popular sports achievements because they arise patriotic feelings. Of the respondents, $89.8 \%$ feel proud when less popular sports national teams gain Olympic medals. A total of $77.7 \%$ of them feel sad when these teams lose. A total of 70.8\% of the Egyptian respondents agree that watching or practicing less popular sports renews their energy to be able to meet the challenges of life. A total of $53 \%$ of them agree that watching less popular sports gives them the opportunity to be with their families and friends. These descriptive statistics results have provided insights to write the practical implications.

\section{Theoretical implications}

This research has developed and tested a conceptual framework that identifies the elements which attract audiences towards less popular sports for the first time. Academic researchers can use sustainable sports marketing as the new name of sports marketing with the aim of having better marketing and better world. Many previous research studies, which discussed different types of less popular sports, have been reviewed and displayed for the first time in one research. This can be a reference for academic researchers in case they need to use in their research studies.

\section{Managerial implications}

Sports organizations need to hire professional marketers to design creative marketing campaigns to increase attraction towards less popular sports. When marketers design sports advertisements, they can depend on ideas that show how less popular sports refresh one's life and increase family ties. Marketers can highlight the achievements of less popular sports national teams when they design marketing campaigns. Marketers can depend on star athletes to attract audiences towards less popular sports. Marketers need to choose star athletes whose manners are highly regarded by audiences to appear in less popular sports advertisements.

High ranking positions in the country can direct different media outlets, especially state media, to make programs about less popular sports and to increase the amount of coverage allocated to less popular sports in the news. Light can be shed on children and young people who are participating in less popular sports. Sports organizations can convince sponsors to support less popular sports as doing part of their corporate social responsibilities. Sponsoring less popular sports can be a new opportunity for companies to exploit to save costs and avoid the crowd of sponsoring popular sports. Supporting less popular sports needs to be a top-down strategy adopted by the country to guarantee the sustainability of supporting these sports. 


\section{Research limitations and future research}

This research is applied only in Egypt. Future research can be done in different countries using facebook messages. This research is a cross-sectional one. Future research may adopt longitudinal research design. Data gathered using online questionnaires have limitations (Malhotra, 2015) because respondents may be enthusiastic and only individuals with access to the internet can be included in the sample. However, facebook messages have allowed the researchers to reach individuals from different governorates of Egypt, which would be difficult to be done if personally administered questionnaire was used.

Although the video in the pretest-posttest experiment is about a handball event, attraction towards less popular sports is measured using a five-point Likert-type scale as mentioned in the methodology section. Future research can be done to investigate the opinions of sponsors regarding supporting less popular sports. Future research can be conducted to examine the impact of movies industry, sports events and social media on attracting audiences towards less popular sports as mentioned by some of the interviewees. Researchers can start to depend on attraction as a variable to build their conceptual models instead of the traditional concepts. Future research can be done to examine the opinions of professionals about sustainable sports marketing definition.

\section{Conclusion}

Sustainable sports marketing can be defined as the continuous implementation of marketing activities in the sports context to ensure the continuous existence of the sports themselves (all types of sports) and the prosperity of future generations. The elements of sports marketing that can help to attract audiences towards less popular sports are sports media, sports advertising, star athlete and sports sponsorship. The performance of national teams moderates the relationship between sports advertising and attraction towards less popular sports.

Audiences can be attracted towards less popular sports if right marketing tools are used. The performance of less popular sports national teams can be the starting point that ignites their attention. Shedding light on less popular sports well-behaved athletes may satisfy audiences' search for role models, away from football players' fights. Audiences appreciate companies which support less popular sports because these companies do their social roles. Audiences encourage less popular sports advertisements and media programs because they will increase their knowledge about these sports. Highlighting children and young people who are participating in less popular sports may help to change future generations' behaviors regarding these sports.

\section{References}

AbouAish, E. (2011), "The effect of celebrity endorsement advertisements on Egyptian youth consumers purchase intentions", Egyptian Business Administartion Review, No. 1, pp. 263-278.

Arai, A., Ko, Y.J. and Kaplanidou, K. (2013), "Athlete brand image: scale development and model test”, European Sport Management Quarterly, Vol. 13 No. 4, pp. 383-403.

Arora, A.S. and Hartley, N. (2017), "Guest editorial: sustainability, institutions and internationalization in emerging markets”, International Journal of Emerging Markets, Vol. 12 No. 1, pp. 2-7.

Baker, M.J. (1976), Marketing: Theory and Practice, The Macmillan Press Ltd., London.

Balbinot, Z. and Borim-De-Souza, R. (2012), "Sustainable development and sustainability as quasiobjects of study in management: a search for styles of reasoning”, Management Research: Journal of the Iberoamerican Academy of Management, Vol. 10 No. 3, pp. 153-186. 
JHASS

4,2

Bee, C.C. and Havitz, M.E. (2010), "Exploring the relationship between involvement, fan attraction, psychological commitment and behavioural loyalty in a sports spectator context", International Journal of Sports Marketing and Sponsorship, Vol. 11 No. 2, pp. 37-54.

Berkman, E.T. and Reise, S.P. (2012), A Conceptual Guide to Statistics Using SPSS, SAGE Publications, Thousand Oaks.

Brown, D. and Bryant, J. (2006), "Sports content on U.S. television”, in Raney, A.A. and Bryant, J. (Eds), Handbook of Sports and Media, Lawrence Erlbaum Associates, Mahwah, NJ, pp. 80-110.

Bryant, A. (2017), Grounded Theory and Grounded Theorizing: Pragmatism in Research Practice, Oxford University Press, New York, NY.

Cialdini, R.B., Borden, R.J., Thorne, A., Walker, M.R., Freeman, S. and Sloan, L.R. (1976), "Basking in reflected glory: three (football) field studies", Journal of Personality and Social Psychology, Vol. 34 No. 3, pp. 366-375.

Creswell, J.W. (2012), Educational Research: Planning, Conducting, and Evaluating Quantitative and Qualitative Research, Pearson, Boston.

Dalakas, V., Madrigal, R. and Anderson, K.L. (2004), “We are number one!' The phenomenon of basking-in-reflected-glory and its implications for sports marketing", in Kahle, L.R. and Riley, C. (Eds), Sports Marketing and the Psychology of Marketing Communication, Lawrence Erlbaum Associates, Mahwah, NJ, pp. 67-79.

Dix, S., Phau, I. and Pougnet, S. (2010), “Bend it like Beckham': the influence of sports celebrities on young adult consumers", Young Consumers, Vol. 11 No. 1, pp. 36-46.

Djaballah, M., Hautbois, C. and Desbordes, M. (2017), "Sponsors' CSR strategies in sport: a sensemaking approach of corporations established in France", Sport Management Review, Vol. 20 No. 2, pp. 211-225.

Ebrahim, M.F.A., Pifer, N.D., Shalaby, S.A.S., El-Hakim, K.M.M., Mubarak, H.E. and Zhang, J. (2018), "Is Egyptian soccer well-positioned for business purposes? Assessing competitive balance in the Egyptian premier league", International Journal of Sports Marketing and Sponsorship, Vol. 19 No. 2, pp. 236-254.

European Commission Report (2016), “Grassroots sport - shaping Europe”, available at: http://ec.europa.eu/ assets/eac/sport/library/policy_documents/hlg-grassroots-final_en.pdf (accessed 13 April 2018).

Field, A. (2013), Discovering Statistics Using IBM SPSS Statistics, SAGE Publications, London.

Filo, K.R., Funk, D.C. and O'Brien, D. (2008), "It's really not about the bike: exploring attraction and attachment to the events of the Lance Armstrong Foundation", Journal of Sport Management, Vol. 22 No. 5, pp. 501-525.

Funk, D.C. (2008), Consumer Behaviour in Sport and Events: Marketing Action, ButterworthHeinemann, Oxford.

Funk, D.C. and James, J. (2001), "The psychological continuum model: a conceptual framework for understanding an individual's psychological connection to sport", Sport Management Review, Vol. 4 No. 2, pp. 119-150.

Girginov, V. and Hills, L. (2008), "A sustainable sports legacy: creating a link between the London Olympics and sports participation", The International Journal of the History of Sport, Vol. 25 No. 14, pp. 2091-2116.

Greenhalgh, G.P. and Greenwell, T.C. (2013), "Professional niche sports sponsorship: an investigation of sponsorship selection criteria", International Journal of Sports Marketing and Sponsorship, Vol. 14 No. 2, pp. 2-19.

Hair, J.F., Jr, Black, W.C., Babin, B.J. and Anderson, R.E. (2014), Multivariate Data Analysis, Pearson, Essex.

Harackiewicz, J.M. and Hulleman, C.S. (2010), “The importance of interest: the role of achievement goals and task values in promoting the development of interest", Social and Personality Psychology Compass, Vol. 4 No. 1, pp. 42-52. 
Hautbois, C. and Bouchet, P. (2015), "Segmenting the spectators of national team sports: the case of a pre-competition match", International Journal of Sports Marketing and Sponsorship, Vol. 16 No. 4, pp. 67-82.

Role of sports marketing

Hidi, S. and Renninger, K.A. (2006), "The four-phase model of interest development", Educational Psychologist, Vol. 41 No. 2, pp. 111-127.

Hoegele, D., Schmidt, S.L. and Torgler, B. (2014a), "Superstars as drivers of organizational identification: empirical findings from professional soccer", Psychology and Marketing, Vol. 31 No. 9, pp. 736-757.

Hoegele, D., Schmidt, S.L. and Torgler, B. (2014b), "Superstars and disloyal football fans: factors influencing attraction to competition", Sport, Business and Management: An International Journal, Vol. 4 No. 4, pp. 298-316.

Hopwood, M. (2007), "The sport integrated marketing communications mix", in Beech, J. and Chadwick, S. (Eds), The Marketing of Sport, Pearson, Essex, pp. 213-238.

Hyman, M.R. and Sierra, J.J. (2010), “Idolizing sport celebrities: a gateway to psychopathology?”, Young Consumers, Vol. 11 No. 3, pp. 226-238.

Inoue, Y., Havard, C.T. and Irwin, R.L. (2016), "Roles of sport and cause involvement in determining employees' beliefs about cause-related sport sponsorship", International Journal of Sports Marketing and Sponsorship, Vol. 17 No. 1, pp. 3-18.

Jang, W., (Eric), Ko, Y.J. and Chan-Olmsted, S.M. (2015), "Spectator-based sports team reputation: scale development and validation", International Journal of Sports Marketing and Sponsorship, Vol. 16 No. 3, pp. 52-72.

Kim, A., Choi, M. and Kaplanidou, K. (2015), "The role of media in enhancing people's perception of hosting a mega sport event: the case of Pyeongchang's Winter Olympics bids agenda setting", International Journal of Sport Communication, Vol. 8 No. 1, pp. 68-86.

Kim(Yongjae), Y., Yim, K. and Ko, Y.J. (2013), "Consumer patriotism and response to patriotic advertising: comparison of international vs. national sport events", International Journal of Sports Marketing and Sponsorship, Vol. 14 No. 3, pp.74-96.

$\operatorname{Kim}(\mathrm{Yu})$, Y.K., Trail, G.T. and Magnusen, M.J. (2013), "Transition from motivation to behaviour: examining the moderating role of identification (ID) on the relationship between motives and attendance", International Journal of Sports Marketing and Sponsorship, Vol. 14 No. 3, pp. 35-56.

Kotler, P. and Armstrong, G. (2016), Principles of Marketing, Pearson, Essex.

Kunz, R.E., Elsässer, F. and Santomier, J. (2016), "Sport-related branded entertainment: the Red Bull phenomenon", Sport, Business and Management: An International Journal, Vol. 6 No. 5, pp. 520-541.

Kwak, D.H., Kwon, Y. and Lim, C. (2015), "Licensing a sports brand: effects of team brand cue, identification, and performance priming on multidimensional values and purchase intentions", Journal of Product and Brand Management, Vol. 24 No. 3, pp. 198-210.

Liu, M.T. and Brock, J.L. (2011), "Selecting a female athlete endorser in China: the effect of attractiveness, match-up, and consumer gender difference", European Journal of Marketing, Vol. 45 Nos 7/8, pp. 1214-1235.

McCracken, G. (1989), "Who is the celebrity endorser? Cultural foundations of the endorsement process", Journal of Consumer Research, Vol. 16 No. 3, pp. 310-321.

Mackintosh, C., Cookson, G. and Griggs, G. (2014), "Reflections on the PING! Table tennis initiative: lessons and new directions for sports development?", International Journal of Public Sector Management, Vol. 27 No. 2, pp. 128-139.

Madrigal, R. (2006), "Measuring the multidimensional nature of sporting event performance consumption", Journal of Leisure Research, Vol. 38 No. 3, pp. 267-292.

Malhotra, N.K. (2015), Essentials of Marketing Research: A Hands-on Orientation, Pearson, Upper Saddle River. 


\section{JHASS \\ 4,2}

Miloch, K.S. and Lambrecht, K.W. (2006), "Consumer awareness of sponsorship at grassroots sport events", Sport Marketing Quarterly, Vol. 15 No. 3, pp. 147-154.

Nakano-Okuno, M. (2011), Sidgwick and Contemporary Utilitarianism, Palgrave Macmillan, Hampshire.

Ngan, H.M.K., Prendergast, G.P. and Tsang, A.S.L. (2011), "Linking sports sponsorship with purchase intentions: team performance, stars, and the moderating role of team identification", European Journal of Marketing, Vol. 45 No. 4, pp. 551-566.

Nkamnebe, A.D. (2011), "Sustainability marketing in the emerging markets: imperatives, challenges, and agenda setting", International Journal of Emerging Markets, Vol. 6 No. 3, pp. 217-232.

Oxford Dictionary (2018a), "Popularity", available at: https://en.oxforddictionaries.com (accessed 18 February 2018).

Oxford Dictionary (2018b), "Sustainability", available at: https://en.oxforddictionaries.com (accessed 18 February 2018).

Plewa, C. and Quester, P.G. (2011), "Sponsorship and CSR: is there a link? A conceptual framework", International Journal of Sports Marketing and Sponsorship, Vol. 12 No. 4, pp. 22-38.

Plutsky, G. (2016), "5 Things we learned about media from the Rio Olympics”, Marketing: Sports, available at: www.mediapost.com/publications/article/283707/5-things-we-learned-about-mediafrom-the-rio-olymp.html (accessed 15 February 2018).

Pyun, D.Y. and James, J.D. (2011), "Attitude toward advertising through sport: a theoretical framework", Sport Management Review, Vol. 14 No. 1, pp. 33-41.

Ramachandran, K.K. (2008), "Sports in the country of a billion: a study of the marketing possibilities and the resulting development of less popular sports in India", in Chadwick, S. and Arthur, D. (Eds), International Cases in the Business of Sport, Butterworth-Heinemann, Oxford, pp. 165-177.

Ratten, V. (2016), "The dynamics of sport marketing: suggestions for marketing intelligence and planning", Marketing Intelligence and Planning, Vol. 34 No. 2, pp. 162-168.

Ritchie, B.W., Shipway, R. and Chien, P.M. (2010), "The role of the media in influencing residents' support for the 2012 Olympic Games", International Journal of Event and Festival Management, Vol. 1 No. 3, pp. 202-219.

Sander, M. and Altobelli, C.F. (2011), "Virtual advertising in sports events: does it really work?", International Journal of Sports Marketing and Sponsorship, Vol. 12 No. 3, pp. $28-42$.

Schlinger, M.J. (1979), "Attitudinal reactions to advertisements", in Eighmey, J. (Ed.), Attitude Research under the Sun, American Marketing Association, Chicago, pp. 171-197.

Schraw, G. and Lehman, S. (2001), "Situational interest: a review of the literature and directions for future research", Educational Psychology Review, Vol. 13 No. 1, pp. 23-52.

Schwarzenberger, V. and Hyde, K. (2013), "The role of sports brands in niche sports subcultures", International Journal of Sports Marketing and Sponsorship, Vol. 15 No. 1, pp. 35-51.

Sekaran, U. (2003), Research Methods for Business: A Skill-Building Approach, John Wiley and Sons, New York, NY.

Shank, M.D. and Lyberger, M.R. (2015), Sports Marketing: A Strategic Perspective, Routledge, New York, NY.

Silvia, P.J. (2006), Exploring the Psychology of Interest, Oxford University Press, New York, NY.

Singh, R. and Simons, J.J.P. (2010), "Attitudes and attraction: optimism and weight as explanations for the similarity-dissimilarity asymmetry", Social and Personality Psychology Compass, Vol. 4 No. 12, pp. 1206-1219.

Söderman, S. and Dolles, H. (2015), "Unlocking advertising, activation and sponsorship in an emerging market: the case of Beijing Olympics", Sport, Business and Management: An International Journal, Vol. 5 No. 5, pp. 472-492. 
Sparks, R. and Westgate, M. (2002), "Broad-based and targeted sponsorship strategies in Canadian women's ice hockey", International Journal of Sports Marketing and Sponsorship, Vol. 4 No. 1, pp. 48-73.

Speed, R. and Thompson, P. (2000), "Determinants of sports sponsorship response", Journal of the Academy of Marketing Science, Vol. 28 No. 2, pp. 226-238.

Trail, G.T. and Kim, Y.K. (2011), "Factors influencing spectator sports consumption: NCAA women's college basketball”, International Journal of Sports Marketing and Sponsorship, Vol. 13 No. 1, pp. 55-77.

Role of sports marketing

Turner, P. (2017), "Implementing integrated marketing communications (IMC) through major event ambassadors", European Journal of Marketing, Vol. 51 No. 3, pp. 605-626.

United Nations (2015), "Sustainable development goals: 17 goals to transform our world", available at: www.un.org/sustainabledevelopment/summit/ (accessed 18 February 2017).

Vann, P., Woodford, D. and Bruns, A. (2015), "Social media and niche sports: the netball ANZ Championship and Commonwealth Games on Twitter", Media International Australia, Vol. 155 No. 1, pp. 108-119.

Vincent, J. and Crossman, J. (2012), "Patriots at play: analysis of newspaper coverage of the gold medal contenders in men's and women's ice hockey at the 2010 Winter Olympic Games", International Journal of Sport Communication, Vol. 5 No. 1, pp. 87-108.

Walker, M. and Kent, A. (2009), "Do fans care? Assessing the influence of corporate social responsibility on consumer attitudes in the sport industry", Journal of Sport Management, Vol. 23 No. 6, pp. 743-769.

Wann, D.L. (1995), "Preliminary validation of the sport fan motivation scale", Journal of Sport and Social Issues, Vol. 19 No. 4, pp. 377-396.

Xu, C., Tian, J., Liu, C. and Wang, Y. (2017), "Spring is coming: WTA and tennis in China: an interview with Mr Fabrice Chouquet, director of WTA and Mr Guoqing Yi”, International Journal of Sports Marketing and Sponsorship, Vol. 18 No. 1, pp. 106-115.

Zeng, G., Go, F. and Kolmer, C. (2011), "The impact of international TV media coverage of the Beijing Olympics 2008 on China's media image formation: a media content analysis perspective", International Journal of Sports Marketing and Sponsorship, Vol. 12 No. 4, pp. 39-56.

\section{Corresponding author}

Dalia Sedky can be contacted at: daliasedkymohamed@gmail.com

For instructions on how to order reprints of this article, please visit our website: 